\title{
Prevalence of Extended-spectrum $\beta$-Lactamase and Quinolone Resistance Genes in Escherichia coli Clinical Isolates and their Antibiotic Resistance
}

\author{
Min Hyeok Lee ${ }^{1,2}$, Yeoung Min Hwang ${ }^{1}$, Keun Sik Baik ${ }^{1,3}$, Hyun Wook Cho ${ }^{1}$ and Chi Nam Seong ${ }^{1}$ * \\ ${ }^{1}$ Department of Biology, College of Life Science and Natural Resources, Sunchon National University, Suncheon 540-742, Korea \\ ${ }^{2}$ Department of Laboratory Medicine, Hankook hospital, Suncheon 540-718, Korea \\ ${ }^{3}$ Department of Biological Sciences, Korea Basic Science Institute, Daejeon 305-806, Korea
}

Received March 7, 2013 /Revised May 16, 2013 /Accepted May 22, 2013

\begin{abstract}
The aim of this study was to investigate the prevalence of Extended-spectrum $\beta$-lactamase (ESBL) gene and quinolone resistance determinant $(q n r)$ and the pattern of antibiotic resistance in the ESBL-producing Escherichia coli clinical isolates. The 42 ESBL-producing strains from total 274 isolates were detected using a double disk synergy test. They were isolated from various specimens, such as urine (28 strains), sputum (6 strains), pus (3 strains), wound (2 strains), blood (2 strains), and tissue (1 strain). Using the PCR with the specific primers ESBL, ESBL and qnr gene types were determined. Thirty-five strains possessed one or two ESBL genes. CTX-M-1 type was the most abundant followed by CTX-M-9 type and TEM, but SHV, CTX-M-2, and CTX-M-8 gene types were not detected. qar gene types were detected from ten isolates in the order of $q n r B 4$, qnrB1, and qnrS. Coexistence of ESBL and qnr genes was found. ESBL-producing isolates showed high resistance against some antibiotics, such as cefotaxmie $(80.0 \%)$, levofloxacin $(82.9 \%)$, and ampicillin $(100 \%)$. Neither a synergy effect from the coexistence of ESBL and $q r r$ genes on antibiotic resistance nor a correlation between the production of qar gene and quinolone resistance were found.
\end{abstract}

Key words : Extended-spectrum $\beta$-lactamase, quinolone resistance, Escherichia coli, antibiotic resistance

\section{서 론}

Extended-spectrum $\beta$-lactamase (ESBL)는 plasmid 매개 효소로서 $\beta$-lactam환을 가수분해하여 oxyimino- $\beta$-lactam 항 생제에 대해 내성을 갖게 한다[9]. 즉, ESBL은 penicillin과 1, 3,4 세대 cephalosporin계열 및 monobactam계열의 aztreonam까지 분해한다[11]. ESBL은 기질 특이성, $\beta$-lactamase 저해제에 의한 효소 활성 억제 정도 등에 따른 분류에서는 group 2be에, 분자구조에 따른 분류에서는 class A에 속한다 [3].

Expanded-spectrum cephalosporin의 광범위한 사용에 의 해 이들 항생제에 내성을 지닌 Klebsiella pneumonia가 출현하 였으며 $[9,24,27]$, 이 후 Escherichia coli와 다른 소수의 그람음 성 세균에서도 내성이 나타나게 되었다[26].

국내에서는 처음으로 2001년 CTX-M-14를 생성하는 E. coli와 K pneumoniae가 보고되었으며[21], 2003년 전국 13개

\footnotetext{
*Corresponding author

Tel : +82-61-750-3613, Fax : +82-61-750-5469

E-mail : scnu@sunchon.ac.kr

This is an Open-Access article distributed under the terms of the Creative Commons Attribution Non-Commercial License (http://creativecommons.org/licenses/by-nc/3.0) which permits unrestricted non-commercial use, distribution, and reproduction in any medium, provided the original work is properly cited.
}

병원에서 분리된 E. coli의 $9 \%$ 가 ESBL을 생성한다고 보고하 였다[23].

ESBL의 여러 가지 유전자형 중 SHV, TEM, CTX-M 등이 널리 보고 되고 있다. 국내에서도 2002년 전국 13 개 병원을 대상으로 조사한 ESBL 출현 현황에서 $E$. coli와 $K$ pneumaniae 가 CTX-M (CTX-M-3, CTX-M-14, CTX-M-15) 유전자를 보유 하고 있다고 하였다[2, 21].

퀴놀론 내성은 fluoroquinolone의 표적 효소인 DNA gyrase와 topoisomerase $\mathrm{IV}$ 의 변이에 의해 유발되거나 efflux pump의 upregulation을 통해 항생제의 축적을 억제함으로써 나타나게 된다 $[5,25]$. DNA gyrase와 topoisomerase IV 효소 에는 퀴놀론 내성 결정부위(quinolone-resistance determining region, QRDR)를 가지고 있어 이 부위의 아미노산이 교체될 경우 fluoroquinolone과의 결합이 억제되어 내성이 나타나게 된다. 퀴놀론 내성 결정 부위 유전자(qnr)는 1994년 미국에서 분리된 $K$ pneumoniae에서 처음 발견되었다[10]. 또한 플라스 미드 매개 퀴놀론 내성(plasmid-mediated quinolone resistance, $\mathrm{PMQR}$ )이 발견되어 퀴놀론에 대한 감수성을 감소시키 고 있다[19]. 국내에서도 2005년도에 한 대학병원에서 분리된 E. coli의 퀴놀론 계 항생제인 ciprofloxacin에 대한 내성률이 $38 \%$ 였음이 보고 된 바 있다[1]. $q n r$ 유전자는 $q n r \mathrm{~A}, q n r \mathrm{~B}$ 와 $q n r S$ 의 유전자형이 알려져 있으며 [29], $q n r$ 유전자의 수평적 확산 기작이 $\mathrm{ESBL}$ 유전자 확산 기작과 유사하여 ESBL 유전자 
와 $q n r$ 유전자를 동시에 보유하는 세균의 출현 빈도가 높아지 고 있다 $[6,12,14]$.

본 연구에서는 2011년 5월부터 2012년 2월까지 전남 순천의 2개 병원의 검체에서 분리된 $E . c o l i$ 균주들을 대상으로 double disk synergy test를 실시하여 ESBL 생성 E. coli 균주를 수집하 였다. 그리고 ESBL 생성 균주들의 ESBL 유전자와 $q n r$ 유전자 의 보유율을 조사하였으며, 항균제 내성 양상을 파악하였다.

\section{재료 및 방법}

\section{E. coli 분리}

2011년 5월부터 2012년 2월까지 전남 순천의 2개 병원의 임상검체로부터 분리된 E. coli 274 주를 이용하였다. 균주의 동정은 BBL Crystal E/NF System (Becton Dickinson, USA) 을 이용하였다.

\section{$\mathrm{ESBL}$ 생성 확인}

ESBL 생성 여부는 double-disk synergy test (DDST) 법을 사용하였다[20]. Mueller-Hinton II agar (MHA; Becton Dickinson, USA)에 MacFarland 0.5 탁도의 균액을 고르게 접 종한 후, 배지의 중앙에는 amoxicillin-clavulanic acid (Oxoid, $30 \mu \mathrm{g}$ ), 주위에는 ceftazidime (Oxoid, $30 \mu \mathrm{g}$ ), cefotaxim (Oxoid, $30 \mu \mathrm{g}$ )와 aztreonam (Oxoid, $30 \mu \mathrm{g}$ ) 디스크를 놓았다. 중앙과 주변 디스크의 가장자리는 $15 \mathrm{~mm}$ 간격이 되게 하였 으며, $37^{\circ} \mathrm{C}$ 에서 16-18시간 배양 후 결과를 판독하였다. 두 디 스크 사이에서 상승효과가 관찰되면 양성으로 판정하였다 (Fig. 1).

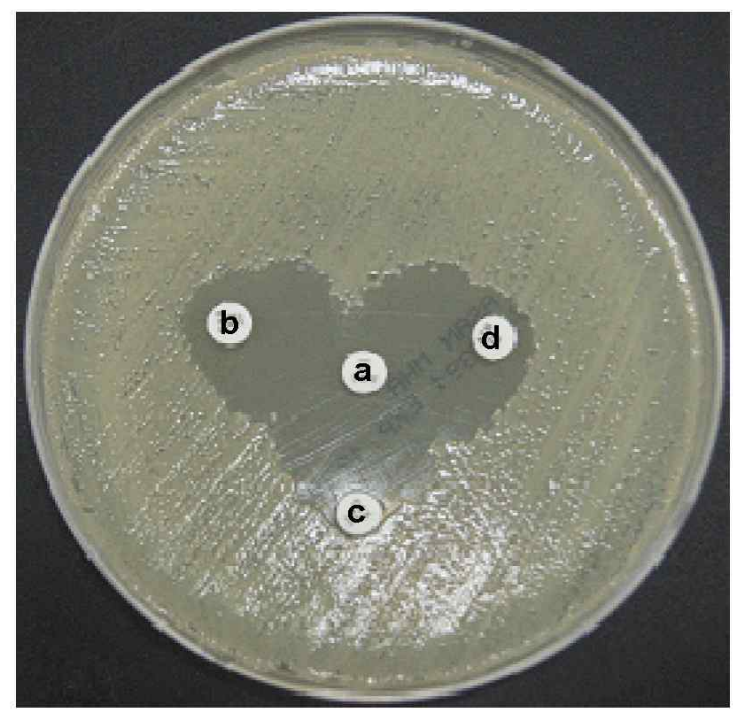

Fig. 1. Photograph of double-disk synergy test with E. coli pro-

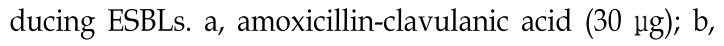
ceftazidime $(30 \mu \mathrm{g}) ; \mathrm{c}$, cefotaxim $(30 \mu \mathrm{g}) ; \mathrm{d}$, aztreonam (30 $\mu \mathrm{g})$.
DNA 추출, ESBL 유전자 및 $9 n r$ 유전자형 분석

MHA배지에 자란 세균 집락 1 loop를 Lysis buffer $[10 \mathrm{mM}$ Tis- $\mathrm{HCl}$ (pH 8.0), 1 mM EDTA, $10 \mathrm{mM} \mathrm{NaCl}, 2 \%$ SDS] 100 lㅣㅇㅘ 2 small spoon의 glass bead (size: $0.4 \mathrm{~mm}$ ) 혼합체에 넣고 10 분간 TOMY mixer (TOMY, USA)에 혼합하였으며, $1 \times \mathrm{TE}$ buffer $200 \mu \mathrm{l}$ 와 phenol : chloroform : isoamyl alcohol (25:24:1) $300 \mu 1$ 를 넣고, 3분간 TOMY mixer에 다시 혼합한 후 원심분리(12,000 rpm, $4 \mathrm{~min})$ 하였다. 상등액을 새로운 tube 에 옮긴 후 RNase A $(20 \mathrm{mg} / \mathrm{ml}) 3 \mu 1$ 를 넣고 $37^{\circ} \mathrm{C}$ 에 30 분간 배양하였고, 0.1 volume의 $3 \mathrm{M}$ sodium acetate $(\mathrm{pH}$ 5.2)와 2 volume의 $100 \%$ ice ethanol을 넣고 $\mathrm{DNA}$ 를 침전 시킨 후 원심분리 $\left(12,000 \mathrm{rpm}, 10 \mathrm{~min}, 4^{\circ} \mathrm{C}\right)$ 하였다. 차가운 $70 \%$ etha$\mathrm{nol}$ 로 세척한 후 건조하여 멸균된 증류수에 녹여 실험에 사용 할 때까지 $-20^{\circ} \mathrm{C}$ 에 냉동 보관하였다.

$\mathrm{ESBL}$ 유전자와 $q n$ 의 여러 유전자형을 검사하기 위해 기존 에 알려진 primer를 이용(Table 1)하여 PCR로 증폭하였다. PCR 반응액은 $\mathrm{dNTP}$ (각 $2.5 \mathrm{mM}$ ), $\mathrm{MgCl}_{2} 2 \mathrm{mM}$, primer 각 20p mol, Taq DNA polymerase (Bioneer, Korea) $0.5 \mathrm{U}$, genomic DNA $100 \mathrm{ng}$ 과 반응완충용액 $(10 \mathrm{mM}$ Tris- $\mathrm{HCl}, 40 \mathrm{mM}$ $\mathrm{KCl}, 1.5 \mathrm{mM} \mathrm{MgCl} 2$ )에 총 부피가 $50 \mu \mathrm{l}$ 가 되도록 증류수를 첨가하였다. PCR 반응은 PTC-150 MiniCycler TM (TaKaRa, Japan)을 이용하였으며 $\mathrm{PCR}$ 반응 조건은 $94^{\circ} \mathrm{C}$ 에서 5 분간 초 기 열처리를 한 후, $94^{\circ} \mathrm{C}$ 에서 30 초, $55^{\circ} \mathrm{C}$ 에서 30 초, $72^{\circ} \mathrm{C}$ 에서 40 초씩 30 회 반복하고 마지막으로 $72^{\circ} \mathrm{C}$ 에서 10 분 동안 더 신장반응을 시켰다. PCR 산물은 $1 \%$ agarose gel에 전기 영동 하여 확인하였다.

\section{항생제 최소억제농도 측정}

각 항생제에 대한 최소억제농도를 Vitek GNS-433 card (bioMeriex, France)로 측정 하였다. MacConkey agar (Becton Dickinson, USA)에서 $37^{\circ} \mathrm{C}, 16$-18시간 배양 된 집락을 사용하 였으며 MacFarland 0.6으로 탁도를 맞춘 균액을 64개의 well 로 구성된 $\mathrm{card}$ 에 넣고, $3^{\circ} \mathrm{C}$ 조건에서 415 시간 배양 후 항생제 의 최소 억제농도를 판독하였다.

\section{결 과}

\section{$\mathrm{ESBL}$ 생성 균주 분리 및 동정}

274개 분리균 중 DDST에 의해 양성으로 나타난 균주는 42 개로 분리빈도는 $15.3 \%$ 에 달했다. 검체별로는 소변에서 가장 많은 28 균주 $(66.7 \%)$ 가 분리되었으며 객담에서 6 균주 $(14.3 \%)$, 농에서는 3 균주, 혈액과 상처에서는 각각 2 균주가 분리되었다 (Table 2).

BBL Crystal E/NF System의 30개의 생화학적 반응에서 arabinose, mannose, rhamnose, sorbitol, galactose, $p$-nitrophenyl $\beta$-galactoside와 p-nitrophenyl bis-phosphate에 대해 
Table 1. Characteristics of nucleotide sequences of PCR primers and anticipated sizes of PCR product used in this study

\begin{tabular}{|c|c|c|c|c|}
\hline Type of genes & Primer & Nucleotide sequence & Fragment size (bp) & GenBank accession No. \\
\hline \multirow{12}{*}{ ESBL } & TEM F & $5^{\prime}$-ctt gaa gac gaa agg gcc tc-3' & \multirow{2}{*}{997} & \multirow{2}{*}{ M36543 } \\
\hline & TEM R & $5^{\prime}$-tga ctc ccc gtc gtg tag at-3' & & \\
\hline & SHV F & $5^{\prime}-\operatorname{cgc} \operatorname{cgg}$ att ctt att $\operatorname{tg}-3^{\prime}$ & \multirow{2}{*}{1,071} & \multirow{2}{*}{ X98100 } \\
\hline & SHV R & $5^{\prime}$-cca cgt tta tgg cgt tac ct- $3^{\prime}$ & & \\
\hline & CTX-M-1F & $5^{\prime}$-gga cgt aca gca aaa act tgc- $3^{\prime}$ & \multirow{2}{*}{183} & \multirow{2}{*}{ X92506 } \\
\hline & CTX-M-1R & $5^{\prime}-\operatorname{cgg}$ ttc gct ttc act ttt ctt-3' & & \\
\hline & CTX-M-2F & $5^{\prime}-\operatorname{cgg} \operatorname{tgc}$ tha aac aga gcg ag- $3^{\prime}$ & \multirow{2}{*}{624} & \multirow{2}{*}{ X92507 } \\
\hline & CTX-M-2R & $5^{\prime}$-cca tga ata agc agc tga ttg $\mathrm{ccc}-3^{\prime}$ & & \\
\hline & CTX-M-8F & $5^{\prime}$-acg ctc aac acc gcg atc- $3^{\prime}$ & \multirow{2}{*}{490} & \multirow{2}{*}{ AF189721 } \\
\hline & CTX-M-8R & $5^{\prime}$-cgt ggg ttc tcg ggg ata a-3' & & \\
\hline & CTX-M-9F & $5^{\prime}$-gat tga $\operatorname{ccg}$ tat tgg gag $\mathrm{ttt}-3^{\prime}$ & \multirow{2}{*}{947} & \multirow{2}{*}{ AJ416345 } \\
\hline & CTX-M-9R & $5^{\prime}-\operatorname{cgg}$ ctg ggt aaa ata ggt ca- $3^{\prime}$ & & \\
\hline \multirow{8}{*}{ Qnr } & qnrA-F & $5^{\prime}$-tca gca aga gga ttt ctc acg- $3^{\prime}$ & \multirow{2}{*}{606} & \multirow{2}{*}{ DQ989302 } \\
\hline & qnrA-R & $5^{\prime}$-ggt tcc agc agt tgc tcc $t-3^{\prime}$ & & \\
\hline & qnrB1-F & $5^{\prime}$-acc tga gcg gca ctg aat tta $t-3^{\prime}$ & \multirow{2}{*}{424} & \multirow{2}{*}{ DQ351241 } \\
\hline & qnrB1-R & $5^{\prime}-\mathrm{tcg}$ caa tgt gtg aag $\mathrm{ttt}$ gc- $3^{\prime}$ & & \\
\hline & qnrB4-F & $5^{\prime}$-gat gac tct ggc gtt agt tgg- $3^{\prime}$ & \multirow{2}{*}{641} & \multirow{2}{*}{ DQ303921 } \\
\hline & qnrB4-R & $5^{\prime}$-cca tga cag cga tac caa ga-3' & & \\
\hline & qnrS-F & $5^{\prime}$-gac gtg cta act tgc gtg at- $3^{\prime}$ & \multirow{2}{*}{380} & \multirow{2}{*}{ DQ449578 } \\
\hline & qnrS-R & $5^{\prime}$-act taa gtc tga ctc ttt cag tga tgc- $3^{\prime}$ & & \\
\hline
\end{tabular}

Abbrivation: F, forward; $R$, reverse

Table 2. Sources of E. coli clinical isolates and prevalence of ESBL-producing strains

\begin{tabular}{lccc}
\hline Specimens & Target strains & No. of positive strains & Ratio $(\%)$ \\
\hline Urine & 206 & 28 & 13.6 \\
Blood & 25 & 2 & 8.0 \\
Pus & 13 & 3 & 23.1 \\
Sputum & 15 & 6 & 4.0 \\
Tissue & 1 & 1 & 100 \\
Wound & 5 & 2 & 40 \\
Body fluid & 2 & 0 & 0 \\
Other & 7 & 0 & 0 \\
\hline Total & 274 & 42 & 15.3 \\
\hline
\end{tabular}

서는 모두 양성을 보였다. 반면 proline nitroanilide, pnitrophenyl xyloside, p-nitrophenyl phosphorylcholine, esculin, p-nitro-DL-phenylalanine, urea, glycine과 malonate에 대해 서는 모두 음성을 나타내었다(자료 생략). 동정 system의 생화 학적 반응 결과로부터 모든 분리균이 E. collo임이 확인되었다.

\section{ESBL 유전자와 $q n r$ 유전자형}

Double-disk synergy test에서 양성을 보인 42균주 중 35균 주에서 PCR에 의해 ESBL 유전자가 검출되었다(Fig. 2). 이 중 11 개 균주는 2 개의 유전자형을 가지고 있었다. ESBL 유전자 중 CTX-M-1을 생성하는 균주가 19균주(45.2\%)로 가장 많았 고, CTX-M-9이 17균주(40.5\%) 그리고 TEM은 10균주(23.8\%) 에서 발견되었다(Table 3). SHV 유전자와 CTX-M-2과 CTX-M-8 은 검출되지 않았다. ESBL 유전자를 2개 이상 보유한 균주는
11 개였으며, 그 구성은 TEM / CTX-M-1 (7균주), TEM / CTX-M-9 (3균주), CTX-M-1 / CTX-M-9 (1균주)였다.

$q n r$ 을 보유한 $q n r$ 양성균주는 10 개 $(23.8 \%)$ 였다. $q n r \mathrm{~B} 4$ 를 보 유한 균주가 7균주 $(16.7 \%)$ 로 가장 많았으며, $q m \mathrm{BB} 1$ 이 2균주 $(4.8 \%), q n r S$ 가 1 균주 $(2.4 \%)$ 에서 검출되었으며 $q m r A$ 는 검출되 지 않았다. ESBL 유전자와 $q n r$ 유전자를 동시에 보유한 균주 는 5개 였으며, 그 구성은 qmrB1 / CTX-M-1 (2균주), qmrS / TEM / CTX-M-1(1균주), qnrB4 / TEM / CTX-M-1 (1균주) 그리고 $q n r B 4 /$ CTX-M-9 (1균주)였다(Table 3).

\section{항생제 내성}

ESBL 생성 E. coli 분리균의 항생제 내성을 $\mathrm{MIC}$ 로 조사한 결과는 Table 4에 나타내었다. Ampicillin에 대해서는 ESBL 유전자 보유 균주(35균주)와 $q a r$ 보유 균주(10균주) 모두가 내 


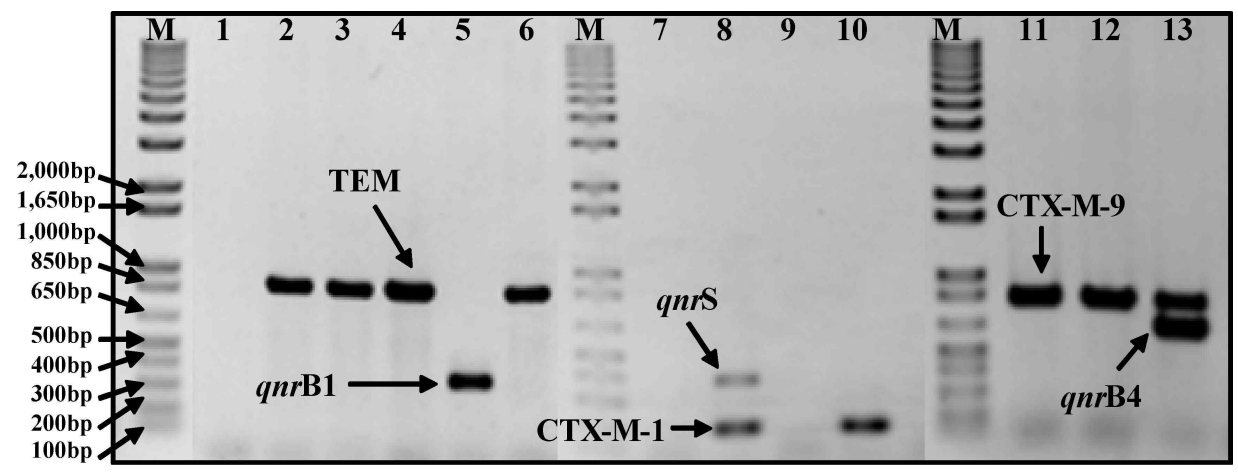

Fig. 2. Agarose gel electrophoresis of the multiplex PCR amplification products from E. coli producing ESBLs. The following primer sets were used: A) TEM, CTX-M-2, qnrB1; B) SHV, CTX-M-1, qnrA, qnrS; C) CTX-M-8, CTX-M-9, qnrB4. Lanes: M, 1 kb plus DNA ladder; lanes1-8, isolates from urine; 9-11, isolates from pus. Lane 3 and 8 and lane 5 and 10 are same DNA samples each.

Table 3. Distribution of ESBL and qnr genes detected in ESBL- producing E. coli clinical isolates

\begin{tabular}{lccccccc}
\hline Type of genes & $\begin{array}{c}\text { Urine } \\
(\mathrm{n}=28)\end{array}$ & $\begin{array}{c}\text { Sputum } \\
(\mathrm{n}=6)\end{array}$ & $\begin{array}{c}\text { Pus } \\
(\mathrm{n}=3)\end{array}$ & $\begin{array}{c}\text { Blood } \\
(\mathrm{n}=2)\end{array}$ & $\begin{array}{c}\text { Wound } \\
(\mathrm{n}=2)\end{array}$ & $\begin{array}{c}\text { Tissue } \\
(\mathrm{n}=1)\end{array}$ & $\begin{array}{c}\text { Total } \\
(\mathrm{n}=42)\end{array}$ \\
\hline CTX-M-1 & 5 & 2 & - & 1 & 1 & - & 9 \\
CTX-M-9 & 8 & 2 & 2 & - & - & - & 12 \\
TEM/CTX-M-1 & 5 & - & - & - & - & - & 5 \\
TEM/CTX-M-9 & 3 & - & - & - & - & - & 3 \\
CTX-M-1/CTX-M-9 & 1 & - & - & - & - & - & 1 \\
CTX-M-1/qnB1 & 2 & - & - & - & - & - & 2 \\
CTX-M-9/qnB4 & - & - & 1 & - & - & - & 1 \\
TEM/CTX-M-1/qnrS & 1 & - & - & - & - & - & 1 \\
TEM/CTX-M-1/qnrB4 & - & - & - & 1 & - & - & 1 \\
qurB4 & 3 & - & - & - & 1 & 1 & 5 \\
None & - & 2 & - & - & - & - & 2 \\
\hline
\end{tabular}

Table 4. Distribution of antibiotic resistant strains of ESBL-producing E. coli clinical isolates

\begin{tabular}{lcccccccc}
\hline \multirow{2}{*}{ Type of genes } & \multirow{2}{*}{ Strains } & \multicolumn{7}{c}{ Number of resistant strain to antibiotics $(\%)$} \\
\cline { 3 - 8 } CTX-M-1 & 9 & 8 & 4 & 6 & 3 & 9 & 4 & 9 \\
CTX-M-9 & 12 & 9 & 0 & 12 & 2 & 10 & 5 & 12 \\
TEM/ CTX-M-1 & 5 & 4 & 0 & 2 & 1 & 3 & 3 & 5 \\
TEM/ CTX-M-9 & 3 & 2 & 0 & 2 & 0 & 2 & 3 & 3 \\
CTX-M-1/CTX-M-9 & 1 & 1 & 0 & 0 & 0 & 1 & 0 & 1 \\
CTX-M-1/ qnrB1 & 2 & 2 & 0 & 2 & 0 & 2 & 2 & 2 \\
CTX-M-9/qurB4 & 1 & 0 & 0 & 0 & 1 & 0 & 0 & 1 \\
TEM/CTX-M-1/ qurS & 1 & 1 & 1 & 1 & 1 & 1 & 0 & 1 \\
TEM/CTX-M-1/ qnrB4 & 1 & 1 & 0 & 1 & 0 & 1 & 0 & 1 \\
qnrB4 & 5 & 3 & 0 & 0 & 0 & 3 & 0 & 5 \\
None & 2 & 1 & 0 & 0 & 1 & 1 & 1 & 2 \\
\hline ESBL gene & 35 & $28(80.0)$ & $5(14.3)$ & $26(74.3)$ & $8(22.9)$ & $29(82.9)$ & $17(48.6)$ & $35(100)$ \\
Qnr & 10 & $7(70.0)$ & $1(10.0)$ & $4(40.0)$ & $2(20.0)$ & $7(70.0)$ & $2(20.0)$ & $10(100)$ \\
Total & 42 & $32(76.2)$ & $5(11.9)$ & $26(61.9)$ & $9(21.4)$ & $33(78.6)$ & $18(42.9)$ & $42(100)$ \\
\hline
\end{tabular}

*Antibiotic (MIC; $\mu \mathrm{g} / \mathrm{ml})$ : CTX, cefotaxime $(\geq 64)$; CAZ, ceftazidime $(\geq 64)$; ATM, aztreonam $(\geq 64)$; AMC, amoxicillin/clavulanate $(\geq 32)$; LEV, levofloxacin $(\geq 8)$; GM, gentamicin ( $\geq 16)$; AMP, ampicillin $(\geq 32)$.

성(MIC $\geq 32 \mathrm{mg} / \mathrm{l})$ 을 나타냈다. ESBL 유전자를 보유한 35균 주 중 3세대 cephalosporin계열의 cefotaxime과 ceftazidime의
$\mathrm{MIC}$ 가 $\geq 64 \mathrm{mg} / 1$ 이상으로 내성인 균주는 각각 28 균주와 5 균 주로 내성율이 $80.0 \%$ 와 $14.3 \%$ 였다. Aztreonam에 대해서는 26 
균주가 MIC $\geq 64 \mu \mathrm{g} / \mathrm{ml}$ 이상을 나타내어 내성율이 $74.3 \%$ 였 다.

CTX-M-9이나 CTX-M-1을 단독으로 보유한 균주의 cefotaxime에 대한 내성 빈도는 $81 \%$ 였으나, $\beta$-lactamase 억제제 가 포함된 amoxicillin-clavulanate에 대해서는 $23.8 \%$ 만 내성 을 보였다(MIC $\geq 32 \mu \mathrm{g} / \mathrm{ml})$. 두개의 유전자를 보유한 균주들 (TEM / CTX-M-1, TEM / CTX-M-9, CTX-M-1 / CTX-M-9)의 cefotaxime과 amoxicillin-clavulanate에 대한 내성 빈도는 각 각 $77.8 \%$ 와 $11.1 \%$ 로서 단독으로 갖는 균주와 큰 차이를 나타 내지 않았거나 더 낮았다.

$q n r$ 양성 균주 중 cefotaxime에 대해 내성인 균주가 7균주였 으며(내성율, $70 \%$ ), ceftazidime에 대해 내성인 균주는 1 균주 였다(내성율, $10 \%$ ). 이는 $\mathrm{ESBL}$ 양성균주의 내성 경향과 유사하 였다.

Quinolone 제제인 levofloxacin에 대해서는 ESBL 유전자 보유 균주 35균주 중 29 균주가 $\mathrm{MIC} \geq 8 \mu \mathrm{gg} / \mathrm{ml}$ 이상으로 $82.9 \%$ 의 내성율을 나타냈으며, $q 7$ 생성균주 10 균주 중 7 균주 가 내성(내성율 $70 \%$ )을 나타냈다. 또한 ESBL 유전자만 보유한 균주에서는 $83.3 \%, \mathrm{ESBL}$ 과 $q n$ 유전자를 동시에 보유한 균주에 서는 $80 \%$ 인데 반해 $q n r$ 유전자만을 보유한 균주에서는 $60 \%$ 였다.

\section{고 찰}

E. coli는 사람이나 동물의 대장에 존재하는 그람음성 간균 으로 대다수 운동성을 가지며, lactose를 분해하며, nitrate를 nitrite로 전환시키는 통성혐기성 세균이다[28]. 숙주의 면역방 어기전이 저하되면 감염의 유발확률이 높으며, 요로감염, 설 사, 패혈증 등을 일으키는 임상에서 가장 흔하게 분리되는 원 내와 원외 감염 세균이다. 최근에는 $\mathrm{ESBL}$ 생성 $\mathrm{E}$. coli의 출현 에 의해 이 세균에 의한 감염의 치료가 문제가 되고 있다. 특히 ESBL 유전자는 플라스미드를 통해 다른 균주로 전파할 수 있 으므로 임상에서 원내감염을 일으킬 수 있는 소지를 가지고 있다[13].

최근 연구에 따르면 E. coli의 8.5-9\%가 ESBL 생성 균주라고 보고한 바 있다 $[8,22]$. 본 연구 결과 순천지역 2개 병원에서 분리된 E. coli 274 균주 중 ESBL 생성 균주는 42 개 균주로 $(15.3 \%)$ 다른 보고에 비해 증가한 수치를 보였다. 유전자형 별로는 CTX-M-1, CTX-M-9과 TEM만 검출되고 SHV, CTX$\mathrm{M}-2, \mathrm{CTX}-\mathrm{M}-8$ 는 검출되지 않았다. 유럽의 경우 CTX-M다음 으로 SHV 유전자도 많이 발견된다는 것과는 차이가 있었으나 [16], 우리나라의 ESBL 양성 E. coli의 유전자형의 일반적인 경향과 일치한다 $[7,15] . \mathrm{SHV}$ 유전자는 본 연구에서 분리되지 않았다. 국내의 다른 연구결과보고에서도 SHV 유전자 보유율 이 5\%[30] 이거나 분리되지 않아[18] 우리나라에서의 SHV 유 전자의 출현빈도는 매우 낮음을 알 수 있다. 또한 최근에 유럽,
캐나다와 아시아에서 장내세균의 CTX-M과 TEM 형 ESBL이 SHV ESBL을 대신하여 가장 흔한 ESBL 유전자형이 되었다는 연구결과와 일치하였다[4] .

본 연구에서 ESBL 생성 균주 중 $q 7 r$ 유전자를 보유한 비율 은 $23.8 \%$ 로 최근 국내의 다른 보고인 $13.5 \%$ 에 비해 다소 높은 비율이었으나[12], 외국에서 보고된 비율과 유사하였다[6]. $q \mathrm{qr}$ 양성 균주 중 $q n R 4$ 의 분리율은 $70 \%$ 였으며, 이는 Enterobacter cloacae를 대상으로 실시한 $q n r$ 양성 균주 아형분석에서 $q n$ B2 가 $56 \%, q n \mathrm{~B} 4$ 가 $22 \%, q n \mathrm{~B} 5$ 가 $22 \%$ 였다는 보고[15]와는 차이 를 보였다. $q u r$ 양성 균주의 ESBL 유전자 보유율은 $50 \%$ 로 국 내의 최근 보고인 $66.7 \%$ 보다는 낮았다[12]. 그러나 $q n r$ 양성 균주의 수가 10 개 이하였던 점으로 미루어 보아 더 많은 균주 를 대상으로 분석할 필요가 있음을 확인하였다.

ESBL 유전자를 보유한 균주의 cefotaxime과 ceftazidime에 대한 내성율은 $80 \%$ 와 $14.3 \%$ 로 ceftazidime 보다 cefotaxime에 대한 가수분해활성이 크다는 것을 알 수 있었다. 특히 cefotaxime에 내성을 지닌 균주 중 amoxicillin/clavulanic acid에 내 성인 균주의 비율이 $21 \%$ 에 이르며, ampicillin에 내성인 균주 의 비율이 $100 \%$ 인 점은 broad-spectrum $\beta$-lactamase (BSBL) 이 만연되어 있음을 시사한다고 할 수 있다. 한편 퀴놀론 계열 인 levofloxacin에 대한 qur 양성 균주의 내성율이 $70 \%$ 였는데, 이 값은 국내의 다른 연구 결과의 $46.8 \%$ [12] 보다는 훨씬 높은 내성율이었다. 특히 $q n r$ 유전자 생성 균주보다 ESBL 생성 균 주의 내성이 더 높은 결과를 나타낸 것은 이 항생 제에 대한 내성이 $q n r$ 유전자와 밀접한 연관성이 없으며 ESBL생성 균주 의 보편적인 특성일 수 있다고 사료된다. 이와 같은 결과는 $q n r$ 생성 균주와 $q n r$ 음성 균주간의 이 항생제에 대한 내성의 차이가 없었거나 음성 균주의 내성율이 더 높았다는 보고를 통해 유추할 수 있다[17]. 이처럼 ESBL 생성 균주들은 cephalosporin계와 fluoroquinolone계 항생제에 높은 내성을 나타 내었으나 $\beta$-lactamase 억제제인 amoxicillin/clavulanate 병합 제제에는 내성율이 낮았다.

DDST를 통해 확인된 ESBL 양성 균주들 중 7개의 균주들에 서는 ESBL 유전자가 검출되지 않았다. 본 연구에서 유전자 검출에 사용한 primer들은 국내에서 발견되는 유전자형을 참 고하여 사용된 것들이다. 따라서 국내에서 검출되지 않았거나 혹은 매우 낮은 검출율을 보인 PER, VEB, GES, IBC, TLA 등 [11] 다양한 class A ESBL 유전자형에 특이적인 primer를 사용 해야 할 필요가 있다는 것을 알 수 있었다.

\section{References}

1. Antimicrobial resistance newsletter. 2006. Antimicrobial resistance of clinical isolates of bacteria in 2005. Ser. No.52.

2. Bae, I. K., Woo, G. J., Jeong, S. H., Park, K. O., Cho, B. K., Kim, D. M., Kwon, S. B., Kim, H. J. and Kang, H. K. 2004. Prevalence of CTX-M-type extended-spectrum $\beta$-lactamase- 
producing Esherichia coli and Klebsiella pneumoniae isolates in Korea. Korean J Clin Microbiol 7, 48-54.

3. Bush, K., Jacoby, G. A. and Medeiros, A. A. 1995. A functional classification scheme for $\beta$-lactamases and its correlation with molecular structure. Antimicrob Agents Chemother 39, 1211-1233.

4. Canton, R. and Coque, T. M. 2006. The CTX-M beta-lactamase pandemic. Curr Opin Microbiol 9, 466-475.

5. Garau, J., Xercavins, M., Rodríguez-Carballeira, M., Gómez-Vera, J. R., Coll, I., Vidal, D., Llovet, T. and Ruíz-Bremón, A. 1999. Emergence and dissemination of quinolone-resistance Escherichia coli in the community. Antimicrob Agents Chemother 43, 2736-2741.

6. Hassan, W. M., Hashim, A. and Domany, R. 2012. Plasmid mediated quinolone resistance determinants $q \mathrm{qr}$, aad $\left(6^{\prime}\right)-\mathrm{Ib}-\mathrm{cr}$, and qep in ESBL-producing Escherichia coli clinical isolates from Egypt. Indian J Med Microbiol 30, 442-447.

7. Hong, J. S., Bae, I. K., Song, E. H., Jeong, S. H., Lee, K. W., Yong, D. E., Lee, J. W., Lee, W. G., Kang, J. O., Ahn, J. Y., Hong, S. K., Shin, J. H., Uh, Y., Park, Y. J., Kim, E. C., Kwak, H. S. and Woo, G. J. 2005. Dissemination of CTX-M type extended-spectrum $\beta$-lactamases and emergence of CTX-M-12 in Escherichia coli. Korean J Lab Med 25, 252-258.

8. Hwang, H. Y., Park, J. S., Bae, I. K., Lee, Y. N. and Jeong, S. H. 2007. Escherichia coli producing CTX-M extended-spectrum $\beta$-lactamase. Kosin Med J 22, 58-67.

9. Jacoby, G. A. and Medeiros, A. A. 1991. More extended-spectrum $\beta$-lactamases. Antimicrob Agents Chemother 35, 1697-1704.

10. Jacoby, G. A., Chow, N. and Waites, K. B. 2003. Prevalence of plasmid-mediated quinolone resistance. Antimicrob Agents Chemother 47, 559-562.

11. Jacoby, G. A. 2006. B-Lactamase nomenclature. Antimicrob Agents Chemother 50, 1123-1129.

12. Jeong, H. S., Bae, I. K., Shin, J. H., Jung, H. J., Kim, S. H., Lee, J. Y., Oh, S. H., Kim, H. R., Chang, C. L., Kho, W. G. and Lee, J. N. 2011. Prevalence of plasmid-mediated quinolone resistance and its association with extended-spectrum beta-lactamase and AmpC beta-lactamase in Enterobacteriaceae Korean J Lab Med 31, 257-264.

13. Jeong, S. H., Bae, I. K., Kwon, S. B., Lee, J. H., Song, J. S., Jung, H. I., Sung, K. H., Jang, S. J. and Lee, S. H. 2005. Dissemination of transferable CTX-M-type extended-spectrum $\beta$-lactamase-producing Escherichia coli in Korea. J Appl Microbiol 98, 921-927.

14. Kang, H. K. 2008. Prevalence of qar genes among clinical isolates of Escherichia coli producing extended-spectrum $\beta$ -lactamase from Korea. Ph.D. Thesis. Kosin University. Korea.

15. Kim, Y. J., Seo, M. R., Kim, J., Choi, E. H., Lee, H. J. and Pai, H. J. 2009. Prevalence and characterization of plasmid-mediated quinolone resistance genes among clinical isolates of extended-spectrum cephalosporin resistant Enterobacter cloacae. Infec Chemother 41, 279-285.

16. Kjerulf, A., Hansen, D. S., Sandvang, D., Hansen, F. and
Frimodt-Møller, N. 2008. The prevalence of ESBL-producing E. coli and Klebsiella strains in the Copenhagen area of Denmark. APMIS 116, 118-124.

17. Lee, C. C., Lui, G., Ip, M., Ling, T. K. and Lee, N. 2012. Frequent detection of plasmid-mediated quinolone resistance $(q n r)$ genes in multidrug-resistant Enterobacteriaceae blood isolates, Hong Kong. Eur J Clin Microbiol Infect Dis 31, 3183-3189.

18. Lee, G. S. 2004. Patterns of antimicrobial resistance and genotyping of extended spectrum $\beta$-Lactamase (ESBL) producing clinical isolates in Korea. M.Sc. Thesis. Yonsei University, Korea.

19. Munshi, M. H., Sack, D. A., Haider, K., Ahmed, Z. U., Rahaman, M. M. and Morshed, M. G. 1987. Plasmid-mediated resistance to nalidixic acid in Shigella dysenteriae type 1. Lancet 2, 419-421.

20. National Committee for Clinical Laboratory Standards. 1993. Performance standards for antimicrobial disk susceptibility tests. Approved standard M2- A5. National Committee for Clinical Laboratory Standards, Villanova, Pa.

21. Pai, H., Choi, E. H., Lee, H. J., Hong, J. Y. and Jacoby, G. A. 2001. Identification of CTX-M-14 extended-spectrum $\beta$ -lactamase in clinical isolates of Shigella sonnei, Escherichia coli, Klebsiella pneumoniae in Korea. J Clin Microbiol 39, 3747-3749.

22. Park, J. H., Lee, S. H., Jeong, S. H., Kim, B. N., Kim, K. B., Yoon, J. D. and Jeon, B. C. 2003. Characterization and prevalence of Escherichia coli and Klebsiella pneumoniae isolates producing an extended-spectrum $\beta$-lactamase from Korean hospitals. Korean J Lab Med 23, 18-24.

23. Park, J. H., Lee, S. H., Jeong, S. H., Kim, K. B., Yoon, J. D. and Jeon, B. C. 2003. Charaterization and prevalence of Escherichia coli and Klebsiela pneumoniae isolate producing an extended-spectrum $\beta$-lactamase from Korea hospital. Korea J Med 23, 18-20.

24. Philippon, A., Labia, R. and Jacoby, G. A. 1989. Extended-spectrum $\beta$-lactamases. Antimicrob Agents Chemother 33, 1131-1136.

25. Robicsek, A., Jacoby, G. A. and Hooper, D. C. 2006. The worldwide emergence of plasmid-mediated quinolone resistance. Lancet Infect Dis 6, 629-640.

26. Sanders, C. C., Barry, A. L., Washington, J. A., Shubert, C., Moland, E. S., Traczewski, M. M., Knapp, C. and Mulder, R. 1996. Detection of extended-spectrum- $\beta$-lactamase-producing members of the family Enterobacteriaceae with Vitek ESBL test. J Clin Microbiol 34, 2997-3001.

27. Sanders, C. C. and Sanders, W. E. Jr. 1992. ß-Lactam resistance in Gram negative bacteria: global trends and clinical impact. Clin Infect Dis 15, 824-839.

28. Scheutz, F. and Strockbine, N. A. 2005. Genus I. Escherichia Castellani and Chalmers 1919, 941 ${ }^{\mathrm{AL}}$. In Bergey's Manual of Systematic Bacteriology, The Proteobacteria, Part B: The Gammaproteobacteria, 2nd eds., vol. 2, pp. 607-625. In: Garrity, G., Brenner, D. J., Krieg, N. R. and Staley, J. R. (eds.), New York: Springer.

29. Wu, J. J., Ko, W. C., Tsai, S. H. and Yan, J. J. 2007. Prevalence 
of plasmid-mediated quinolone resistance determinants $q n r \mathrm{~A}, q n r \mathrm{~B}$, and $q u r S$ among clinical isolates of Enterobacter cloacae in a Taiwanese hospital. Antimicrob Agents Chemother 51, 1223-1227.
30. Yoo, Y. 2008. In vitro susceptibility against piperacillin/ tazobactam and ESBL genotypes of Escherichia coli and Klebsiella pneumonia producing extended-spectrum $\beta$ lactamase. M.Sc. Thesis. Konkuk University, Korea.

\section{초록 : 임상검체로부터 분리된 Escherichia coli의 Extended-spectrum $\beta$-lactamase와 퀴놀론 내성 유전자 의 출현빈도 및 항생제 내성}

이민혁 ${ }^{1,2} \cdot$ 황영민 ${ }^{1} \cdot$ 백근식 ${ }^{1,3} \cdot$ 조현욱 $\cdot$ 성치남 ${ }^{1}$

( ${ }^{1}$ 순천대학교 생물학과, ${ }^{2}$ 순천한국병원 진단검사의학과, ${ }^{3}$ 한국기초과학지원연구원)

본 연구에서는 ESBL을 생성하는 Escherichia coli의 Extended-spectrum $\beta$-lactamase (ESBL) 유전자와 퀴놀론 내성결정부위 $(q n r)$ 의 유전자형과 항생제 내성 양상을 규명하고자 하였다. 임상검체에서 분리 된 E. coli 274개 균 주를 대상으로 double-disk synergy test 검사를 실시하여 42개의 ESBL 생성 균주를 분리하였다. 검체별로는 소 변에서 28 균주가 분리되었으며, 객담에서 6 균주, 농에서 3 균주, 상처에서 2균주, 혈액에서 2균주 그리고 조직에서 1 균주가 분리되었다. 이 균주들을 대상으로 $\mathrm{ESBL}$ 유전자와 퀴놀론 내성 유전자를 PCR을 이용하여 검색하였다. 35 개의 균주가 1 개 혹은 2 개의 ESBL 유전자를 보유하고 있었다. ESBL 유전자의 분포는 CTX-M-1이 가장 많았으 며, CTX-M-9과 TEM 유전자 순이었다. SHV, CTX-M-2와 CTX-M-8는 검출되지 않았다. $q n r$ 유전자는 10개 균주에 서 검출되었으며 유전형별로는 $q n \mathrm{nB} 4, q n \mathrm{nB} 1, q n \mathrm{rS} 1$ 순이었다. 2가지 이상의 $\mathrm{ESBL}$ 유전자를 동시에 보유한 균주 와 ESBL과 $q n r$ 유전자를 동시에 보유한 균주가 검출되었다. ESBL 유전자 보유균주는 cefotaxmie $(80.0 \%)$, levofloxacin $(82.9 \%)$ 과 ampicillin $(100 \%)$ 에 고도내성을 보였다. $q 7 r$ 유전자 보유 균주의 cefotaxmie, levofloxacin과 ampicillin에 대한 내성율은 각각 $70 \%, 70 \%, 100 \%$ 였다. ESBL 유전자들간의 그리고 $q n r$ 유전자와의 동시 보유가 항생제 내성에 미치는 상승효과는 없었다. $q n r$ 유전자 보유와 퀴놀론에 대한 내성 사이의 상관관계도 없었다. 